Review Article

\title{
Medical Microbiology in India: The Recent Developments in the Basic Research, Diagnostics and Vaccines
}

\author{
JUGSHARAN SINGH VIRDI ${ }^{1, \#, *}$, NEELJA SINGHAL ${ }^{1, \#}$, ANAY KUMAR MAURYA ${ }^{1}$, \\ THANDAVARAYAN RAMAMURTHY ${ }^{2}$, PRIYA SINGH ${ }^{3}$ and NIRJARA SINGHVI ${ }^{3}$ \\ ${ }^{1}$ Microbial Pathogenicity Laboratory, Department of Microbiology, University of Delhi South Campus, \\ New Delhi 110 021, India \\ ${ }^{2}$ Translational Health Science and Technology Institute, Faridabad 121 001, Haryana, India \\ ${ }^{3}$ Department of Zoology, University of Delhi, Delhi 110 007, India
}

(Received on 03 April 2019; Accepted on 04 November 2019)

\begin{abstract}
Medical microbiology being the largest subset under microbiology brings out the benefits of the research in the field of microbiology for the welfare of the masses through applied medical science. Researchers around the globe are working tirelessly in this field in order to prevent, diagnose and treat infectious diseases well in time. India being a tropical country with poor socio-economic conditions and slack healthcare schemes has wide range and burden of the infectious diseases. This has led to the researchers here to take up the challenging tasks of medical microbiology research, they are actively working and the present article reviews the exemplary contribution of these researchers from India in the last decade. This enlists the basic research carried to assess the infections caused by Rotavirus, Human Immunodeficiency Virus (HIV), Pathogenic Vibrios, Mycobacterium tuberculosis, M. leprae, Salmonella enterica servovar typhi, Helicobacter pylori, Yersinia enterocolitica, Leptospires, Leishmania, Plasmodium falciparum, P. vivax, Wuchereria bancrofti, Entamoeba histolytica and some other pathogens. The knowledge gathered through the basic research has been applied for the development of certain vaccines and diagnostic tools and/or techniques to tackle infectious diseases. Notably, Mycobacterium Indicus Prani vaccine (against certain Mycobacterial infections), Rotavac (against rotavirus), JENVAC (against Japanese encephalitis), recombinant vaccine DENVs (against dengue virus) etc. have been developed by Indian research groups and have found wide application. The present article briefly reviews such breakthrough developments in the field of applied microbiology along with a concise account of the infectious diseases outbreaks that resulted from inadequate containments of the vectors.
\end{abstract}

Keywords: Epidemicity; Pathogens; Gastroenteritis; Genotypes; Serovars

\section{Introduction}

India with its variety of climatic conditions, demography, rich flora and fauna and wide socioeconomic spectrum constitute an ideal niche for the emergence and spread of infectious diseases caused by pathogenic microorganisms. Consequently, microbiologists from India have contributed significantly in understanding the epidemiology, basic and applied aspects on biology of infectious agents. This article covers the recent research outcomes of important pathogens.

\section{Basic Research}

\section{Rotavirus}

Rotavirus is the most common cause of gastroenteritis (vomiting and severe diarrhea) among infants and young children. Rotavirus infections can cause mild to severe disease characterised by vomiting, watery diarrhoea and low-grade fever. The genotypes of the human and animal rotaviruses circulating in India have been extensively studied (Saluja et al., 2017). The human and bovine-human re-assortment rotaviruses in children with gastroenteritis in hospitals, the neonatal nurseries and in community settings (Babji et al., 2014;

*Authorfor Correspondence: E-mail: virdi_dusc@rediffmail.com; ${ }^{\# C o n t r i b u t e d ~ e q u a l l y ~}$ 
John et al., 2014; Kang et al., 2015) have brought new understanding about this virus.

\section{Human Immunodeficiency Virus (HIV)}

HIV is a lentivirus that causes the viral infection and over time acquired immunodeficiency syndrome (AIDS). AIDS in turn causes the progressive failure of the immune system allowing life-threatening opportunistic infections and cancers to thrive. The genetic heterogeneity of HIV-1 strains circulating in different parts of India has been investigated (Khan et al., 2007; Seth 2010). More than 95\% isolates circulating in India belonged to the subtype-C. This information was instrumental in undertaking research for designing an HIV vaccine for Indian population. A new subtype; Thai-B was identified in Manipur, which was different from the subtype B, the most prevalent HIV-1 strain in the US and Europe (Sarkar et al., 2011).

\section{Pathogenic Vibrios}

Vibrios are the Gram-negative bacteria and few of the species can cause foodborne infection, usually associated with eating undercooked food or untreated/ unsafe water. Several species of vibrios were associated with acute diarrhoea and other systemic infections. The epidemicity and endemicity of cholera caused by $V$. cholerae serogroups $\mathrm{O} 1$ and $\mathrm{O} 139$ are well investigated in several findings (Kanungo et al., 2010; Ramamurthy and Sharma, 2014; Chowdhury et al., 2016; Sharma et al., 2017). The genome of $V$. cholerae is continuously changing, as evidenced by variation in the biotype encoding and cholera toxin encoding genes (Mukhopadhyay et al., 2014; Das et al., 2016). The importance of other serovars (other than $\mathrm{O} 1$ and $\mathrm{O} 139$ ) of $V$. cholerae in causing the cholera-like diarrhoea has been emphasized in a study from Kolkata (Dutta et al., 2013). Emergence of $V$. fluvialis associated with hospitalized acute diarrhoea cases has also been reported from Kolkata (Chowdhury et al., 2012). The appearance and global spread of $V$. parahaemolyticus $\mathrm{O} 3: \mathrm{K} 6$ and other serovars had several epidemiological implications (Nair et al., 2007). In fact, this event was the first to demonstrate the emergence of pandemic clones in this species.

\section{Mycobacterium tuberculosis}

Tuberculosis has been a rampant health threat worldwide and has been the most devastating in the under-developed and developing countries around the world. India has a substantial burden of patients suffering from tuberculosis caused by Mycobacterium tuberculosis. Several studies helped to identify new genotypes, dynamics and dissemination of this pathogen (Chauhan et al., 2007; Haldar et al., 2007; Lavania et al., 2007; Sharma et al., 2008; Gupta et al., 2010, Chauhan et al., 2011; Gautam et al., 2014; Sikri et al., 2015; Kaur et al., 2016). Using genetic typing of M. tuberculosis isolates from India, presence of ancestral isolates as the predominant form circulating in India has been shown which could explain the lack of concordance between bacterial load and disease burden in the Indian population (Rao et al., 2006; Ahmed et al., 2009; Ahmed and Hasnain, 2011; Thomas et al., 2012). Studies on functional characterization of $M$. tuberculosis hypothetical PE/ PPE protein family revealed their importance in diagnostics, as vaccine candidates and as drug targets (Akhter et al., 2012; Kohli et al., 2012; Parsa and Hasnain, 2015). The genetic diversity and drug susceptibility profile of $M$. tuberculosis isolated from different regions, safety and tolerability profiles of antitubercularmedications have also been studied in detail (Swaminathan, 2014; Ramachandran and Swaminathan, 2014). Additionally, there was a study from the Indian subcontinent that took intoaccount the shift in the bacterial community of gut and the functional implications of microbes on the gut-lung axis,especially during tuberculosis (Maji et al., 2018; Sood et al., 2018).

\section{Mycobacterium leprae}

Data obtained from the National Leprosy Eradication Programme (NLEP) has shown the reduction in cases from $57.8 / 10,000$ in 1983 to $0.66 / 10,000$ in 2016. Globally, India continues to account for $60 \%$ of new cases and from 2007 to 2016, the number remained the same with almost 1.35 lakh new cases (Rao and Suneetha, 2018). Several other works have been done on the detection of $M$. leprae, its drug resistance and vaccines (Lavania et al., 2015)

\section{Salmonella enterica serovar typhi}

Enteric fever is an important public-health problem 
in India. The clinical presentation of typhoid fever caused by Salmonella enterica serovar typhi was found to be highly variable. The estimated prevalence of $S$. typhi detected through culture or serology across all hospital-based studies in the random effects model was 9.7\% (John et al., 2016). The meta-regression revealed a significant decline in laboratory confirmed typhoid among patients with fever or suspected typhoid. Apart from causing typhoid fever, S. typhi was found to be significantly associated with gallbladder cancer (Tewari et al., 2010). A diverse population of $S$. typhi with H58 haplotypes was detected with multidrug and quinolone resistance (Holt et al., 2012). Variable number tandem repeatPCR analysis also showed high genetic variability within the S. typhi strains (Sankar et al., 2013). Ciprofloxacin has become the first-line drug of choice for the treatment of typhoid due to the widespread emergence and spread of strains resistant to chloramphenicol, ampicillin and trimethoprim. Recently, there is also increase in the occurrence of strains resistant to ciprofloxacin (Harish et al., 2011; Patel et al., 2017).

\section{Helicobacter pylori}

Cytotoxic H. pylori were isolated more frequently from patients with peptic ulcers, than from patients suffering from gastritis, the milder form of the disease (Shanjana and Ayyagari, 2003). Exaggerated apoptosis was found to play an important role in $H$. pylorimediated gastric diseases, including carcinogenesis (Tiwari et al., 2008). The frequency of $H$. pylori infection in patients suffering from gastric neoplasms was detected more by endoscopy than serology.

DNA sequence information has helped in understanding the evolution of $H$. pylori, its survival and adaptation through genomic changes (Devi et al., 2010; Avasthi et al., 2011). This study also helped to understand the natural history of $H$. pylori in the context of human anthropology (Ahmed et al., 2008; Devi et al., 2006; Alvi et al., 2007). Whole genome microarrays, pan-island sequencing and full genome sequencing revealed that though parts of the pathogenicity islands were seen to rearrange over time, these rearrangements did not bring about significant change in severity of pathology of the disease (Prouzet-Mauleon et al., 2005; Alvi et al., 2007).

\section{Yersinia enterocolitica}

Y. enterocolitica is an important food and waterborne zoonotic enteropathogen. The first outbreak of gastroenteritis due to this bacterium was reported in 1996. The organism has been isolated from wastewater, pork, pigs and the stools of the diarrhoeic patients. These strains belonged to several serotypes. Genotyping using REP- and ERIC-PCRs showed that the strains belonged to two clonal groups indicating their narrow genetic heterogeneity (Sachdeva and Virdi, 2004). Similar results were inferred from genotyping based on $r r n$ and gyrB loci. Sequencing of $\beta$-lactamase genes (blaA, blaB) also discerned two clonal groups (A and B) as based on repetitive extragenic palindrome- and enterobacterial repetitive intergenic consensus-PCR genotyping (Sharma et al., 2006; Singhal et al., 2014; Singhal et al., 2015). These studies also showed that the serotypes 6,30-6,31 isolated from wastewater were genotypically different from the serotype 6,30-6,31 isolated from diarrhoeal patients (Mallik and Virdi, 2010).

The detection of a large number of virulenceassociated genes (inv, ail, virF, yst $A, y s t B, y s t C, m y f A$, fep $A$, fepD, fes, hreP, ymoA, tcc C, sat) showed that the $Y$. enterocolitica strains belonged to low virulence biotype 1A group (Bhagat and Virdi, 2007). Multilocus variable number tandem repeat analysis (MLVA), multilocus enzyme electrophoresis (MLEE) and multilocus restriction typing (MLRT) and their analysis by minimum spanning tree and e-BURST suggested that the clinical strains probably originated from environmental strains by host adaptation and genetic change (Mallik and Virdi, 2010).It has also been reported that the interaction of these bacteria with cultured cell depends on characteristics of the individual strains and not the clonal groups. Interestingly, some functional parameters did not reflect the two clonal groups. A variety of studies have reported the presence of virulence factors in these bacterial strains. One of the reported factors is presence of iron- acquisition system and wellregulated iron homeostasis. Suppression subtractive hybridization between clinical and environmental strains and proteomic analysis indicated the presence of several iron-acquisition and storage genes showed up-regulation or down-regulation during conditions of iron depletion or iron repletion (Kanaujia et al., 2015). 


\section{Leptospires}

Leptospirosis is primarily a zoonotic disease, which may be transmitted to human beings. It is caused by a pathogenic spirochete of the genus Leptospira that traditionally consist of two species, Leptospira inter rogans (the pathogenic serovars) and Leptospira biflexa (the saprophytic serovars). The Leptospira serovars predominantly identified include $L$. andamana, L. pomona, L. grippotyphosa, L. hebdomadis, L. semoranga, L. javanica, L. autumnalis, L. canicola (https://www.ncdc.gov.in/ ). Most outbreaks of leptospirosis have been reported from the coastal regions of Gujarat, Maharashtra, Orissa, West Bengal, Kerala, Tamil Nadu, Karnataka and the Andaman Islands (Divya et al., 2017). Outbreaks have also occurred in the recent years in different parts of the country, including the 2007 outbreak in Karnataka (http://www.gideononline.com), 2011 and 2012 outbreak in Gujarat (http:// www.healthmap.org).

Leptospires from patients suffering from Andaman hemorrhagic fever was associated with high fatality in Andaman Islands (Sharma et al., 2006; Lall et al., 2016). Valbuzzi is a common infective serovar of leptospires responsible for pulmonary complications in Andaman Islands (Vijaychari et al., 2003).

\section{Leishmania}

Visceral leishmaniasis (VL, also known as kala-azar), is caused by intracellular protozoan, Leishmania. India has reported the largest number of VL cases, accounting for $40 \%-50 \%$ of the world's disease burden (Agarwal et al., 2017). Most of the research is focused largely on the clinical and epidemiological aspects of the disease. To date, there is no effective vaccine available. However, treatment of VL is based only on chemotherapy i.e. a single dose of liposomal amphotericin B (L-AmB) and multidrug therapy [L$\mathrm{AmB}+$ miltefosine, $\mathrm{L}-\mathrm{AmB}+$ paromomycin $(\mathrm{PM})$, or miltefosine+PM] (Singh et al., 2016). National Vector Borne Disease Control Program (NVBDCP) of India recommends sodium stibo gluconate or miltefosine for the treatment of VL and post kala-azar dermal leishmaniasis (PKDL) (Saha et al., 2017).

\section{Plasmodium falciparum and P. vivax}

Malaria in India is mainly caused by $P$. vivax with
$53 \%$ of the estimated cases. In 2014 alone, about 380,000 malaria cases were recorded, which is nearly a sixth of total cases reported globally (Anvikar et al., 2016). Chloroquine resistant $P$. falciparum has emerged since 1973. Sulfa-pyrimethamine is a new first-line drug for treatment of this pathogen (Shah et al., 2011). The epidemiology of $P$. vivax is very complex, including multiple relapse phenotypes with varying latencies and resistant to control measures. Calcium-dependent protein kinases (CDPKs) were found to play a critical role in different life cycle of Plasmodium including secretion of adhesions, cell invasion, gamete maturation, and motility (Kadian et al., 2017).

\section{Wuchereria bancrofti}

Lymphatic filariasis is mainly caused by the parasite W.bancrofti. India contributes to $41 \%$ of global lymphatic filariasis (Agarwal and Sashindran, 2011). Data collected in 2006 exhibited the prevalence of 31 million microfilaraemics, 23 million cases of symptomatic filariasis, and about 473 million individuals potentially at risk of infection in the country (Agrawal et al., 2006). Annual single-dose treatment with diethylcarbamazine along and albendazole for three consecutive years has shown significant reduction in the lymphatic filariasis (Kshirsagar et al., 2017). Therapeutic prospects of biopolymer functionalized gold nanoparticles against filarial parasite has been established through nuclear factor erythroid-derived Nrf2. These nanoparticles induced oxidative stress and apoptotic cell death in filarial parasites is mediated through mitochondria. A new $70-\mathrm{kDa}$ microfilarial protein that binds to macrophage-Toll-like receptor 4 and triggers nuclear factor kappa beta activation that upregulates secretion of proinflammatory cytokines has been discovered (Mukherjee et al., 2017). Functional analysis of this protein would help in understanding the host-parasite relationship and immunopathogenesis of filarial infection. Genetic polymorphism studies revealed the existence of three variant $W$. bancrofti glutathione S-transferase (WbGST) alleles in the four filarial endemic regions. Mutational impact on the functions of Wb-GST highlights the mechanisms of parasite survival against the host oxidative stress environment (Sakthidevi et al., 2013). 


\section{Entamoeba histolytica}

Amoebiasis still remains one of the major public health problems for developing countries like India. People's access to clean water, hygienic food and proper sanitation is limited to certain places and because of this most people get exposed to deadly diseases like amoebiasis. It is caused by enteric protozoan parasite Entamoeba histolytica. Indian researchers have contributed variously to check the infection, its rapid detection and treatment (Anwar et al., 2018; Mukhopadhyay et al., 2002; Nath et al., 2015; Pandey et al., 2018; Zaman et al., 2018). The work has been carried out in order to manage the disease in best possible manner as this infectious organism is here to stay pertaining to unhygienic conditions. The prevalence of this disease is more in developing countries due to lack of advanced diagnostic methodologies. Diagnosis of the disease is based on various techniques like microscopy, culture and serology based techniques. RT-PCR has been reported to be one of the best and most sensitive method to confirm the tests, also confirmed by WHO. But due to its expensive equipment and cumbersome routine diagnostic, this technique has not been successfully employed in limited resources nations (Dhanalakshami and Parija, 2016).

\section{Other Pathogens}

Many studies pertaining to the respiratory syncytial virus, their genetic variability, molecular detection of human caliciviruses with special emphasis to Norwalklike viruses (NLVs) and Sapporo-like viruses (SLVs), molecular epidemiology, genotyping and viral load assays of Polioviruses, the study of genetic variability of other respiratory viruses have demonstrated the role of some other viral pathogens (Banarjee et al., 2007; Rachakonda et al., 2008; Bharaj et al., 2009; Mir et al., 2012; Broor et al., 2014; Raghuram et al., 2015). Several pathogens associated with diphtheria (2000), plague (1994-2004), H1N1 (2009), Chandipura virus (2003), chikungunya virus (2005) and Congo haemorrhagic virus (2011) were found to be emerged/re-emerged in the country (Dikid et al., 2013).

\section{Diagnostics}

In the last two-decade or so, with the introduction of state-of-art scientific infrastructure and facilities in several laboratories and support from the funding agencies like Department of Biotechnology (DBT) and its associated Biotechnology Industry Research Assistance Council (BIRAC), many scientists have undertaken research and development related to the diagnosis of infectious diseases. This development has been further aided by the establishment of a large number of Technology Based Incubators (TBIs) in several states of the country.

A test kit for the on-site detection of HIV antibodies (HIV-1 and HIV-2) in two minutes has been developed using a drop of blood (Gupta and Chaudhary, 2003).Recently, an indigenously developed technology for dengue NS1 antigen detection has been successfully transferred for commercial production and use. Since then, a large number of dengue NS1 Antigen tests have been carried out by the laboratories in India to detect and diagnose dengue infection in the country (http://www.icgeb.org/navin-khanna.html).

A rapid test for identification and confirmation of TB has also been developed. The test is based on the detection of two M. tuberculosis specific antigens using high affinity monoclonal antibodies. The research carried out at the Defence Research and Development Establishment (Gwalior) has resulted in the development of kits for rapid and real-time detection of emerging viruses of public health importance. The diagnostic kits have made use of several newer techniques like RT-PCR, Multiplex PCR, Real-Time PCR and RT-LAMP (Parida et al., 2011; Sharma et al., 2011; Kumar et al., 2012; Parida et al., 2016).

Blood culture remains gold standard for diagnosis. Widal test has low sensitivity and specificity, but may be used in second week to support the diagnosis. Salivary anti-Salmonella typhi lipopolysaccharide IgA antibody-based ELISA has been developed and tested in children with typhoid fever (Zaka-ur-Rab et al., 2012). An immunoassay using using Ag-labeled nano-conjugated antigen was developed for the rapid detection of $S$. typhi and $S$. paratyphi antibodies in serum samples (Chattopadhyay et al., 2014).

A nested multiplex PCR based diagnosis was developed for the detection of virulent S. typhi from the patient's blood samples (Prabagaran et al., 2017). This M-PCR targets first the flagellin gene (fliC) 
followed by the detection of Via B operon of Salmonella Pathogenicity Island-7 (PI-7) that comprises tviA and tviB genes. This M-PCR can be used to detect Vi-negative Typhi serovar in typhiod endemic regions, where the $\mathrm{Vi}$ vaccine has been administered. Additional cases of Salmonella Paratyphi A and non-typhoidal Salmonella can be detected with the PCR screen made with $f l i C$ and iro $B$ that encodes glycosyl transferases (Ganesan et al., 2014).

Molecular and serological tests for analysis and diagnosis of Leptospira species prevalent in India have also been developed (Ahmed et al., 2006; Natarajaseenivasan et al., 2008). Several different simple and rapid tests such as Lepto-dipstick, Leptolateral flow, Leptodri-dot, Linnodee etc. for the diagnosis of leptospirosis (Vijayachari and Sehgal, 2006; Sehgal et al., 1999). Microscopic examination of tissue smears is a gold standard for the definitive diagnosis of VL and PKDL. Loop-mediated isothermal amplification (LAMP) assay with DNA from biological samples, immunochromatographic test with anti-rK-39 antibodies and latex agglutination test using serum samples were successfully evaluated (Boelaert et al., 2014).

Ziehl-Neelsen (ZN) staining technique using smears from ear lobe, skin lesion, and normal skin and histopathology of specimens stained with hematoxylin and eosin and Wade-Fite stain are clinically used for the detection of M. leprae. In addition, serum anti-PGL1 levels, fine needle aspiration cytology from the affected nerve, and M. lepraespecific multiplex PCR were also used in the routine practice. Fluorescent staining method was found to be more sensitive than modified fite-faraco and $\mathrm{ZN}$ staining techniques (Adiga et al., 2016). M. lepraespecific repetitive element PCR was found to be superior compared to other PCR targetting the rpoT, SodA and 16S rRNA genes (Turankar et al., 2015).

Apart from direct microscopy, several useful protein antigens were targeted in the rapid diagnosis of malaria (Patankar et al., 2017).

Based on WbSXP-1, the chimeric peptides for the detection of anti-SXP antibody was found to be reactive, specifically with microfilareamic sera by ELISA. These peptide-based ELISA is useful in the diagnosis of lymphatic filariasis (Pandiaraja et al., 2010). Monoclonal antibodies against recombinant WbSXP-1 has also been tested in the rapid-antibodyflow-through diagnostic kit for filariasis (Janardhan et al., 2011).

\section{Vaccines}

The live oral vaccine VA 1.4 was developed for the first-time using $V$. cholerae O1 El Tor strain that was genetically engineered to contain only the immunogenic subunit of the cholera toxin (Thungapathra et al., 1999). In field trials, this vaccine was found to be highly safe and immunogenic (Mahalanabis et al., 2009). Many potential candidate vaccine strains for typhoid have been prepared. In animal studies, the recombinant Omp-28 protein elicited strong protection against virulent Salmonella typhi (Saxena et al., 2017). OmpR attenuated strains of $S$. typhi may be used as good candidate strains for the development of live attenuated vaccine against salmonellosis (Senthilkumar et al., 2014).

A rotavirus vaccine containing a G9P(11) human strain (116E) isolated from an Indian child was developed as part of the Indo-US Vaccine Action Program. This vaccine (now Rotavac) is well tolerated and immunogenic in several clinical trials. $\mathrm{Mw}$ is an immunoprophylactic and an immunotherapeutic vaccine, developed in India, for multibacillary leprosy. The vaccine is based on a non-pathogenic Mycobacterium, now named as Mycobacterium indicus pranii (MiP) (Talwar et al., 2016). The National Leprosy Eradication Programme has initiated the Mycobacterium Indicus prani vaccine in 2016. This vaccine has both immunotherapeutic and immune-prophylactic effects (Rao and Suneetha, 2018).

Japanese encephalitis, a mosquito-borne viral infection, is the most common cause of viral encephalitis in certain parts of India, especially eastern Uttar Pradesh, Bihar and Bengal, claiming several lives every year (Tiwari et al., 2012). Mortality is higher among children and many individuals who were inflicted by this infection have been disabled for life by its sequelae. Scientists have developed a method for growing the Japanese encephalitis virus (Jev) in cell lines and its inactivation (Kalia et al., 2013). This simple and inexpensive method of growing Jev was 
transferred to $\mathrm{M} / \mathrm{s}$ Panacea Biotech for the development of India's first indigenous vaccine against Japanese encephalitis called JENVAC (Singh et al., 2015). This vaccine is to be manufactured in the publicprivate partnership between the Indian Council of Medical Research (ICMR) and M/s Bharat Biotech (http://pib.nic.in/newsite/erelease.aspx?relid=99873). The vaccine provides increased immunity and longterm protection due to its unique manufacturing technologies. A recombinant vaccine made from the major 'envelope proteins' of dengue viruses, which protects against four closely related dengue viruses (DENVs) has also been developed.

Scientists have developed a genetically engineered vaccine against anthrax, a disease caused by Bacillus anthracis which has the potential to be used as an agent of bioterrorism (Goel, 2015; Dhasmana et al., 2014; Singh et al., 1999; Singh et al., 1998; Kaur et al., 2013). The technology of recombinant anthrax vaccine was transferred to $\mathrm{M} / \mathrm{s}$ Panacea Biotec Ltd. (https://www.panaceabiotec.com/).

A collaboration between Indian scientists have developed a DNA vaccine which is targeted to be used both for veterinary and human use (Kumar et al., 2013). This is a combination rabies vaccine (CRV) in which both a DNA vaccine and a conventional cell culture grown attenuated rabies vaccine have been combined (Garg et al., 2014; Bharati et al., 2013). Once the efficacy and the safety of the vaccine has been proved in the veterinary use its further development for use in humans are on the agenda (Biswas et al., 2001; Kumar et al., 2006; Kumar et al., 2013).Several studies have also been carried out

\section{References}

Adiga DS, Hippargi SB, Rao G, Saha D, Yelikar BR and Karigoudar M (2016) Evaluation of fluorescent staining for diagnosis of leprosy and its impact on grading of the disease: comparison with conventional staining $J$ Clin Diagn Res $1023-26$

Agarwal P, Kumar V, Kaushal M, Kumari M and Chaudhary A (2017) Indian visceral leishmaniasis with extensive lymphadenopathy - An unusual presentation: A case report with literature review Cytojournal 149

Ahmed N, Dobrindt U, Hacker J and Hasnain SE (2008) Genomic for the development of vaccine for Mycobacterium tuberculosis, including identification of possible drug targets (Jain et al., 2008; Deyet al., 2010; Khare et al., 2011; Dey et al., 2011; Jatana et al., 2011).

A DNA vaccine encoding the Indian subtype C sequences and using an attenuated vaccinia virus as a vector has been developed by the scientists. The prototype MVA(vector)-based potential AIDS vaccine (TBC-M4), is currently undergoing trials.A detailed investigation into HIV have been provided by the scientists working in India (Khan et al., 2007; Seth, 2010).

A subunit vaccine formulation based on recombinant envelope proteins of Chikungunya virus has also been developed (Khan et al., 2012). Several P. falciparum transmission blocking vaccines are now under trial stage (Chaturvedi et al., 2016). Prophylactic efficacy of the chimeric epitope vaccine with a filarial epitope protein (FEP) has been successfully tested in a murine model (Anugraha et $a l ., 2015)$. This FEP has generated multiple types of protective immune responses with effective obliteration of the parasite.

\section{Outbreak Investigations}

India has developed several initiatives for investigating and containment of outbreaks caused by infectious agents. Integrated Disease Surveillance Programme (IDSP) was initiated in 2004 to strengthen the disease surveillance system and to investigate and respond to disease outbreaks promptly. Through a network system (www.idsp.nic.in), IDSP receives disease outbreak reports from all the States/UTs on a weekly basis.

fluidity and pathogenic bacteria: applications in diagnostics, epidemiology and intervention Nat Rev Microbiol 6 387-394

Agrawal VK and Sashindran VK (2006) Lymphatic filariasis in India: problems, challenges and new initiatives Med $J$ Armed Forces India 62 359-362

Ahmed N, Devi SM, Valverde Mde L, Vijayachari P, Machangu RS, Ellis WA and Hartskeerl RA (2006) Multilocus sequence typing method for identification and genotypic classification of pathogenic Leptospira species Ann Clin Microbiol Antimicrob 5 28-37 
Ahmed N, Ehtesham NZ and Hasnain SE (2009) Ancestral Mycobacterium tuberculosis genotypes in India: Implications for TB control programme Infect Gen Evol 9 142-146

Ahmed N and Hasnain SE (2011) Molecular epidemiology of tuberculosis in India: moving forward with a systems biology approach Tuberculosis (Edinb) 91 407-413

Akhter Y, Ehebauer MT, Mukhopadhyay S and Hasnain SE (2012) The PE/PPE multigene family codes for virulence factors and is a possible source of mycobacterial antigenic variation: perhaps more? Biochimie 94 110-116

Alvi A, Devi SM, Ahmed I, Hussain MA, Rizwan M, Lamouliatte $\mathrm{H}$, Mégraud F and Ahmed N (2007) Microevolution of Helicobacter pylori type IV secretion systems in an ulcer disease patient over a ten-year period J Clin Microbiol 45 4039-4043

Anugraha G, Madhumathi J, Prince PR, Prita PJ, Khatri VK, Amdare NP, Reddy MV and Kaliraj P (2015) Chimeric epitope vaccine from multistage antigens for lymphatic filariasis Scand J Immunol 82 380-389

Anvikar AR, Shah N, Dhariwal AC, Sonal GS, Pradhan MM, Ghosh SK and Valecha N Epidemiology of Plasmodium vivax Malaria in India Am J Trop Med Hyg 95 108-120

Anwar T and Samudrala G (2018) Bioinformatics Analysis and Functional Prediction of Transmembrane Proteins in Entamoeba histolytica Genes 9499

Arora J, Kumar G, Verma AK, Bhalla M, Sarin R and Myneedu VP (2015) Utility of MPT64 antigen detection for rapid confirmation of Mycobacterium tuberculosis complex $J$ Global Infect Dis 7 66-69

Avasthi TS, Devi SH, Taylor TD, Kumar N, Baddam R, Kondo S, Suzuki Y, Lamouliatte H, Mégraud F and Ahmed N (2011) Genomes of two chronological isolates (Helicobacter pylori 2017 and 2018) of the West African Helicobacter pylori strain 908 obtained from a single patient $J$ Bacteriol $1933385-3386$

Babji S, Arumugam R, Sarvanabhavan A, Gentsch JR and Kang G (2014) Approach to molecular characterization of partially and completely untyped samples in an Indian rotavirus surveillance program Vaccine 32 A84-A88

Banerjee S, Bharaj P, Sullender W, Kabra SK and Broor S (2007) Human metapneumovirus infections among children with acute respiratory infections seen in a large referral hospital in India J Clin Virol 38 70-72

Bhagat N and Virdi JS (2007) Distribution of virulence-associated genes in Yersinia enterocolitica biovar 1A correlate with clonal groups and not the source of isolation FEMS
Microbiol Lett 266 177-186

Bharaj P, Sullender WM, Kabra SK, Mani K, Cherian J, Tyagi V, Chahar HS, Kaushik S, Dar L and Broor S (2009) Respiratory viral infections detected by multiplex PCR among pediatric patients with lower respiratory tract infections seen at an urban hospital in Delhi from 2005 to 2007 Virol J 689

Bharati K and Vrati S (2013) DNA vaccines: Getting closer to becoming a reality Indian J Med Res 137 1027-1028

Biswas S, Reddy GS, Srinivasan VA and Rangarajan PN (2001) Pre-exposure efficacy of a novel combination DNA and inactivated rabies virus vaccine Hum Gene Ther 12 19171922

Broor S, Dawood FS, Pandey BG, Saha S, Gupta V, Krishnan A, Rai S, Singh P, Erdman D and Lal RB (2014) Rates of respiratory virus-associated hospitalization in children aged $<5$ years in rural northern India J Infect 68 281-289

Boelaert M, Verdonck K, Menten J, Sunyoto T, van Griensven J, Chappuis F and Rijal S (2014) Rapid tests for the diagnosis of visceral leishmaniasis in patients with suspected disease Cochrane Database Syst Rev 6 1-119

Chattopadhyay S, Dey SK, Maiti P and Dolai D (2014) A novel tool for capture and detection of typhoid fever using Aglabeled nanocomposites J Biol Inorg Chem 19 1377-1384

Chaturvedi N, Bharti PK, Tiwari A and Singh N (2016) Strategies $\&$ recent development of transmission-blocking vaccines against Plasmodium falciparum Indian J Med Res 143 696-711

Chauhan DS, Sharma VD, Parashar D and Chauhan A (2007) Molecular typing of Mycobacterium tuberculosis isolates from different parts of India based on IS6110 element polymorphism using RFLP analysis Indian J Med Res 125 577-581

Chauhan S, Sharma D, Singh A, Surolia A and Tyagi JS (2011) Comprehensive insights into Mycobacterium tuberculosis DevR (DosR) regulon activation switch Nucleic Acids Res 239 7400-7414

Chowdhury G, Bhadra RK, Bag S, Pazhani GP, Das B and Basu P (2016) Rugose atypical Vibrio cholerae O1 El Tor responsible for 2009 cholera outbreak in India $J$ Med Microbiol 65 1130-1136

Chowdhury G, Pazhani GP, Dutta D, Guin S, Dutta S, Ghosh S, Izumiya H, Asakura M, Yamasaki S, Takeda Y, Arakawa E, Watanabe H, Mukhopadhyay AK, Bhattacharya MK, Rajendran K, Nair GB and Ramamurthy T (2012) Vibrio fluvialis in patients with diarrhea, Kolkata, India Emerg Infect Dis 18 1868-1871 
Das B, Pazhani GP, Sarkar A, Mukhopadhyay A K, Nair GB and Ramamurthy T (2016) Molecular evolution and functional divergence of Vibrio cholera Curr Opin Infect Dis 29520 527

Devi SM, Ahmed I, Khan AA, Rahman SA, Alvi A, Sechi LA and Ahmed N (2006) Genomes of Helicobacter pylori from native Peruvians suggest admixture of ancestral and modern lineages and reveal a western type cag-pathogenicity island BMC Genomics 7191

Devi SH, Taylor TD, Avasthi TS, Kondo S, Suzuki Y, Megraud F and Ahmed N (2010) Genome of Helicobacter pylori strain 908 J Bacteriol 192 6488-6489

Dey B, Jain R, Khera A, Gupta UD, Katoch VM, Ramanathan VD and Tyagi AK (2011) Latency antigen $\alpha$-crystalin based vaccination imparts a robust protection against $\mathrm{TB}$ by modulating the dynamics of pulmonary cytokines $P l o S$ One 6 e18773

Dey B, Jain R, Khera A, Rao V, Dhar N, Gupta UD, Katoch M V, Ramanathan VD and Tyagi AK (2010) Boosting with a DNA vaccine expressing ESAT-6 (DNAE6) obliterates the protection imparted by recombinant BCG (rBCGE6) against aerosol Mycobacterium tuberculosis infection in guinea pigs Vaccine 28 63-70

Dhanalakshmi S and Parija SC(2016) Seroprevalence of Entamoeba histolytica from a tertiary care hospital, South India.Trop Parasitol 6 78-81

Dhasmana N, Singh LK, Bhaduri A, Misra R and Singh Y (2014) Recent developments in anti-dotes against anthrax Recent Pat Antiinfect Drug Discov 9 83-96

Dikid T, Jain SK, Sharma A, Kumar A and Narain JP (2013) Emerging \& re-emerging infections in India: an overview Indian J Med Res 138 19-31

Divya SK, Sreedhara HG, Hirannaiah CR and Mohan NK (2017) Seroepidemiological Study of Leptospirosis among Clinically Suspected Cases Int J Curr Microbiol App Sci 6 134-141.

Dutta D, Chowdhury G, Pazhani GP, Guin S, Dutta S, Ghosh S, Rajendran K, Nandy RK, Mukhopadhyay AK, Bhattacharya MK, Mitra U, Takeda Y, Nair GB and Ramamurthy T (2013) Vibrio cholerae non-O1, non-O139 serogroups and cholera-like diarrhea, Kolkata, India Emerg Infect Dis 19 464-467

Ganesan V, Harish BN, Menezes GA and Parija SC (2014) Detection of Salmonella in blood by PCR using iroB gene J Clin Diagn Res 8 1-3

Garg R, Kaur M, Saxena A and Bhatnagar R (2014) DNA vaccination for rabies: Evaluation of preclinical safety and toxicology Trials Vaccinol 3 73-80

Gautam US, Sikri K, Vashist A, Singh V and Tyagi JS (2014) Essentiality of DevR/DosR interaction with SigA for the dormancy survival program in Mycobacterium tuberculosis J Bacteriol 196 790-799

Goel AK (2015) Anthrax: A disease of biowarfare and public health importance World J Clin Cases 3 20-33-

Government of India. Press release from Press Information Bureau: Shri Ghulam Nabi Azad launches JE Vaccine (JENVAC) produced by NIV, ICMR and Bharat Biotech. New Delhi: Ministry of Health and Family Welfare, Government of India; October 4, 2014. Available from: http://pib.nic.in/ newsite/erelease.aspx? relid $=99873$, accessed on November 27, 2018.

Gupta A and Chaudhary VK (2003) Whole-blood agglutination assay for on-site detection of human immunodeficiency virus infection J Clin Microbiol 41 2814-2821

Gupta AK, Katoch VM, Chauhan DS, Sharma R, Singh M, Venkatesan K and Sharma VD (2010) Microarray analysis of efflux pump genes in multidrug-resistant Mycobacterium tuberculosis during stress induced by common antituberculous drugs Microb Drug Resist 16 21-28

Haldar S, Chakravorty S, Bhalla M, De Majumdar S and Tyagi JS (2007) Simplified detection of Mycobacterium tuberculosis in sputum using smear microscopy and PCR with molecular beacons J Med Microbiol 56 1356-1362

Holt KE, Dutta S, Manna B, Bhattacharya SK, Bhaduri B, Pickard DJ, Ochiai RL, Ali M, Clemens JD and Dougan G (2012) High-resolution genotyping of the endemic Salmonella typhi population during a $\mathrm{Vi}$ (typhoid) vaccination trial in Kolkata PLoS Negl Trop Dis 6 e1490

Jain R, Dey B, Dhar N, Rao V, Singh R, Gupta UD, Katoch VM, Ramanathan VD and Tyagi AK (2008) Enhanced and enduring protection against tuberculosis by recombinant BCG-Ag85C and its association with modulation of cytokine profile in lung PLoS One3 e3869

Janardhan S, Pandiaraja P, Pandey V, Karande A and Kaliraj P (2011) Development and characterization of monoclonal antibodies against WbSXP-1 for the detection of circulating filarial antigens J Helminthol85 1-6

Jatana N, Jangid S, Khare G, Tyagi AK and Latha N (2011) Molecular modeling studies of fatty acyl-CoA synthetase (FadD13) from Mycobacterium tuberculosis - a potential target for the development of antitubercular drugs $J \mathrm{Mol}$ Model 17 301-313

John J, Sarkar R, Muliyil J, Bhandari N, Bhan MK and Kang G (2014) Rotavirus gastroenteritis in India, 2011-2013: 
revised estimates of disease burden and potential impact of vaccines Vaccine 32 5-9

John J, Van Aart CJ and Grassly NC (2016) The Burden of Typhoid and Paratyphoid in India: Systematic Review and Meta-analysis PLoS Negl Trop Dis 10 e0004616

Kadian K, Gupta Y, Kempaiah P, Gupta N, Sharma A and Rawat M (2017) Calcium dependent protein kinases (CDPKs): Key to malaria eradication Curr Top Med Chem 172215 2220

Kalia M, Khasa R, Sharma M, Nain M and Vrati S (2013) Japanese encephalitis virus infects neuronal cells through a clathrinindependent endocytic mechanism J Virol 87 148-162

Kanaujia PK, Bajaj P, Kumar S, Singhal N and Virdi JS (2015) Proteomic analysis of Yersinia enterocolitica biovar 1A under iron-rich and iron-poor conditions indicate existence of efficiently regulated mechanisms of iron homeostasis $J$ Proteomics 124 39-49

Kang G, Tate JE and Parashar UD (2015) Evaluation of rotavirus disease burden and vaccine effectiveness in India Vaccine 337143

Kanungo S, Sah BK, Lopez AL, Sung JS, Paisley AM, Sur D, Clemens JD and Nair GB (2010) Cholera in India: an analysis of reports, 1997-2006 Bull World Health Organ 8 185-191

Kaur K, Kumari P, Sharma S, Sehgal S and Tyagi JS (2016) DevS/ DosS sensor is bifunctional and its phosphatase activity precludes aerobic DevR/Dos Rregulon expression in Mycobacterium tuberculosis FEBS J 283 2949-2962

Khan IF, Vajpayee M, Prasad VV and Seth P (2007) Genetic diversity of HIV type 1 subtype $\mathrm{C}$ env gene sequences from India AIDS Res Hum Retroviruses 23 934-940

Khan MI, Dhanwani R, Rao PV and Parida M (2012) Subunit vaccine formulations based on recombinant envelope proteins of Chikungunya virus elicit balanced Th1/Th2 response and virus-neutralizing antibodies in mice Viral Immunol 25 153-160

Khare G, Kar R and Tyagi AK (2011) Identification of inhibitors against Mycobacterium tuberculosis thiamin phosphate synthase, an important target for the development of AntiTB drugs PLoS One 6 e22441

Kohli S, Singh Y, Sharma K, Mittal A, Ehtesham NZ and Hasnain SE (2012) Comparative genomic and proteomic analyses of PE/PPE multigene family of Mycobacterium tuberculosis $\mathrm{H} 37 \mathrm{Rv}$ and H37Ra reveal novel and interesting differences with implications in virulence Nucleic Acids Res 407113 7122

Kshirsagar NA, Gogtay NJ, Garg BS, Deshmukh PR, Rajgor
DD, Kadam VS, Thakur PA, Gupta A, Ingole NS and Lazdins-Helds JK (2017) Efficacy and tolerability of treatment with single doses of diethylcarbamazine (DEC) and DEC plus albendazole (ABZ) for three consecutive years in lymphatic filariasis: a field study in India Parasitol Res16 2683-2694

Kumar BD, Kumar PU, Krishna TP, Kalyanasundaram S, Suresh P, Jagadeesan V, Hariharan S, Naidu AN, Krishnaswamy K, Rangarajan PN and Srinivasan VA (2013) Pre-clinical toxicity \&immunobiological evaluation of DNA rabies vaccine $\&$ combination rabies vaccine in rhesus monkey (Macacamulatta) Indian J Med Res 137 1072-1088

Kumar J, Khan M, Gupta G, Bhoopati M, LakshmanaRao PV and Parida M (2012) Production, characterization, and application of monoclonal antibodies specific to recombinant (E2) structural protein in antigen-capture ELISA for clinical diagnosis of Chikungunya virus Int $J$ Infect Dis 16 53-59

Kumar S, Aggarwal P, Vajpayee M, Pandey RM and Seth P (2006) Development of a candidate DNA/MVA HIV-1 subtype C vaccine for India Vaccine 24 2585-2493

Lall C, Kumar KV, Raj RV, Vedhagiri K and Vijayachari P (2016) Prevalence and diversity of Leptospires in different ecological niches of urban and rural areas of south Andaman Island Microbes Environ 31 79-82

Lavania M, Katoch K, Singh H, Das R, Gupta AK, Sharma R, Chauhan D S, Sharma V D, Sachan P, Sachan S and Katoch VM (2007) Predominance of three copies of tandem repeats in rpoT gene of Mycobacterium leprae from Northern India Infect Genet Evol 7 627-631

Lavania M, Jadhav R, Turankar RP, Singh I, Nigam A and Sengupta U (2015) Genotyping of Mycobacterium leprae strains from a region of high endemic leprosy prevalence in India Infect Genet Evol 36 256-261

Maji A, Misra R, Dhakan DB, Gupta V, Mahato NK, Saxena R, Mittal P, Thukral N, Sharma E, Singh A, Virmani R, Gaur M, Singh H, Hasija Y, Arora G, Agarwal A, Chaudhry A, Khurana JP, Sharma VK, Lal R and Singh Y (2018) Gut microbiome contributes to impairment of immunity in pulmonary tuberculosis patients by alteration of butyrate and propionate producers Environ Microbiol $20402-419$

Mallik S and Virdi JS (2010) Genetic relationships between clinical and non-clinical strains of Yersinia enterocolitica biovar $1 \mathrm{~A}$ as revealed by multilocus enzyme electrophoresis and multilocus restriction typing BMC Microbiol 10 158-172

Mahalanabis D, Ramamurthy T, Nair GB, Ghosh A, Shaikh S, Sen B, Thungapathra M, Ghosh RK, Pazhani GP, Nandy RK, Jana S and Bhattacharya SK (2009) Randomized 
placebo controlled human volunteer trial of a live oral cholera vaccine VA1.3 for safety and immune response Vaccine 27 4850-4856

Mir MA, Lal RB, Sullender W, Singh Y, Garten R, Krishnan A and Broor S (2012) Genetic diversity of HA1 domain of hemagglutinin gene of pandemic influenza H1N1pdm09 viruses in New Delhi, India J Med Virol 84 386-393

Mukherjee S, Mukherjee S, Maiti T K, Bhattacharya S and Sinha Babu SP (2017) A novel ligand of toll-like receptor 4 From the sheath of Wuchereria bancrofti microfilaria induces proinflammatory response in macrophages $J$ Infect Dis 215 954-965

Mukhopadhyay A, Chakraborti A, Mahajan RC and Ganguly NK (2002) Entamoeba histolytica: rapid identification and differentiation of Indian isolates by riboprinting. Exp Parasitol 102 109-112

Mukhopadhyay A K, Takeda Y and Balakrish Nair G (2014) Cholera outbreaks in the El Tor biotype era and the impact of the new El Tor variants Curr Top Microbiol Immunol 379 17-47

Nair GB, Ramamurthy T, Bhattacharya SK, Dutta B, Takeda Y and Sack DA (2007) Global dissemination of Vibrio parahaemolyticus serotype O3:K6 and its serovariants Clin Microbiol Rev 20 39-48

Natarajaseenivasan K, Vijayachari P, Sharma S, Sugunan AP, Selvin J and Sehgal SC (2008) Serodiagnosis of severe leptospirosis: evaluation of ELISA based on the recombinant OmpL1 or LipL41 antigens of Leptospirainterrogans serovar autumnalis Ann Trop Med Parasitol 102 699-708

Nath J, Ghosh SK, Singha B and Paul J (2015) Molecular epidemiology of amoebiasis: a cross-sectional study among North East Indian population PLoS Negl Trop Dis 3 e0004225

Pandey S, Gupta GK, Wanjari SJ and Nijhawan S (2018) Comparative study of tinidazole versus metronidazole in treatment of amebic liver abscess: A randomized control trial Indian J Gastroenterol 37 196-201

Pandiaraja P, Arunkumar C, Hoti SL, Rao DN and Kaliraj P (2010) Evaluation of synthetic peptides of WbSXP-1 for the diagnosis of human lymphatic filariasis Diagn Microbiol Infect Dis 68 410-415

Parida M, Dash PK, Kumar JS, Joshi G, Tandel K, Sharma S, Srivastava A, Agarwal A, Saha A, Saraswat S, Karothia D and Malviya V (2016) Emergence of influenza A (H1N1) genogroup 6B and drug resistant virus, India Euro Surveillance 21 6-11
Parida M, Shukla J, Sharma S, Ranghia S, Ravi V, Mani R, Thomas M, Khare S, Rai A, Ratho R, Pujari S, Mishra B, LakshmanaRao PV and Vijayaraghavan R (2011) Development and evaluation of reverse transcription loopmediated isothermal amplification assay for rapid and realtime detection of the swine-origin influenza A H1N1 virus J Mol Diagn 13100-107

Parsa K and Hasnain SE (2015) Proteomics of multidrug resistant Mycobacterium tuberculosis clinical isolates: A peep show on mechanism of drug resistance and perhaps more Indian J Med Res 141 114-115

Patankar S, Sharma S, Rathod P K and Duraisingh M T (2017) Malaria in India: The need for new targets for diagnosis and detection of Plasmodium vivax Proteomics Clin Appl 12 e 1700024

Patel SR, Bharti S, Pratap CB and Nath G (2017) Drug Resistance pattern in the recent isolates of Salmonella typhi with special reference to Cephalosporins and Azithromycin in the Gangetic Plain J Clin Diagn Res 11 DM01-DM03

Prabagaran SR, Kalaiselvi V, Chandramouleeswaran N, Deepthi KNG, Brahmadathan K N and Mani M (2017) Molecular diagnosis of Salmonella typhi and its virulence in suspected typhoid blood samples through nested multiplex PCR $J$ Microbiol Methods 139 150-154

Prouzet-Mauléon V, Hussain M A, Lamouliatte H, Kauser F, Mégraud F and Ahmed N (2005) Pathogen evolution in vivo: genome dynamics of two isolates obtained 9 years apart from a duodenal ulcer patient infected with a single Helicobacter pylori strain J Clin Microbiol 43 4237-4241

Rachakonda G, Choudekar A, Parveen S, Bhatnagar S, Patwari A and Broor S (2008) Genetic diversity of noroviruses and sapoviruses in children with acute sporadic gastroenteritis in New Delhi, India $J$ Clin Virol 43 42-48

Raghuram SV, Khan WH, Deeba F, Sullender W, Broor S and Parveen S (2015) Retrospective phylogenetic analysis of circulating BA genotype of human respiratory syncytial virus with $60 \mathrm{bp}$ duplication from New Delhi, India during 2007-2010 Virus Disease 26 276-281

Ramachandran G and Swaminathan S (2015) Safety and tolerability profile of second-line anti-tuberculosis medications Drug Saf 38 253-269

Ramamurthy T and Sharma NC (2014) Cholera outbreaks in India Curr Top Microbiol Immunol 79 49-85

Rao KR, Kauser F, Sriramula S, Sechi LA, Ahmed N and Hasnain SE (2006) Analysis of genomic downsizing based on region of difference (RD) polymorphism profiling of Mycobacterium tuberculosis patient isolates reveals 
geographic partitioning J Clin Microbiol 43 5978-5982

Rao PN and Suneetha S (2018) Current situation of leprosy in India and its future implications Indian Dermatol Online $J$ 9 83-89

Sachdeva P and Virdi JS (2004) Repetitive elements sequence (REP/ERIC) - PCR based genotyping of clinical and environmental strains of Yersinia enterocoliticabiotype 1A reveal existence of limited number of clonal groups FEMS Microbiol Lett 240 193-201

Saha P, Ganguly S, Chatterjee M, Das SB, Kundu PK, Guha SK, Ghosh TK, Bera DK, Basu N and Maji AK (2017) Asymptomatic leishmaniasis in kala-azar endemic areas of Malda district, West Bengal, IndiaPLoS Negl Trop Dis 11 e0005391

Saluja T, Dhingra MS, Sharma SD, Gupta M, Kundu R, Kar S, Dutta AK, Silveira MD, Singh JV, Kamath VG, Chaudhary A, Rao V, Ravi MD, Murthy K, Arumugam R, Moureau A, Prasad R and Patnaik BN (2016) Association of rotavirus strains and severity of Gastroenteritis in Indian children Hum Vaccin Immunother 13 711-716

Sakthidevi M, Prabhu PR, Chowdhary S, Hoti SL and Kaliraj P (2013) Functional analysis of genetic polymorphism in Wuchereriabancrofti glutathione S-transferase antioxidant gene: impact on protein structure and enzyme catalysis Mol Biochem Parasitol 192 10-20

Sankar S, Kuppanan S, Nandagopal B and Sridharan G (2013) Diversity of Salmonella enterica serovar Typhi strains collected from India using variable number tandem repeat (VNTR)-PCR analysis Mol Diagn Ther 17 257-64

Sarkar R, Pal R, Bal B, Mullick R, Sengupta S, Sarkar, K and Chakrabarti S (2011) Genetic characterization of HIV-1 strains among the injecting drug users in Nagaland, India Open Viro J 5 96-103

Saxena A, Kumar R and Saxena MK (2017) Vaccination with Salmonella typhi recombinant outer membrane protein 28 induces humoral but non-protective immune response in rabbit Vet World 10 946-949

Sehgal S C, Vijayachari P, Sharma S and Sugunan AP (1999) Lepto Dipstick: a rapid and simple method for serodiagnosis of acute leptospirosis Trans $R$ Soc Trop Med Hyg 93 161-164

Senthilkumar B, Anbarasu K, Senbagam D and Rajasekarapandian M (2014) Induction of deletion mutation on ompR gene of Salmonella entericaserovartyphi isolates from asymptomatic typhoid carriers to evolve attenuated strains for vaccine development Asian Pac J Trop Med 7 933-939

Seth P (2010) Evolution of HIV-1 in India Indian J Virol 21 3-7
Shah NK, Dhillon GP, Dash AP, Arora U, Meshnick SR and Valecha N (2011) Antimalarial drug resistance of Plasmodium falciparum in India: changes over time and space Lancet Infect Dis 11 57-64

Shanjana A and Ayyagari A (2003) Cytotoxic isolates of Helicobacter pylori from peptic ulcer diseases decrease $\mathrm{K}+$-dependent ATPase activity in HeLa cells $B M C$ Gastroenterol 331

Sharma P, Chauhan DS, Upadhyay P, Faujdar J, Lavania M, Sachan S, Katoch K and Katoch VM (2008) Molecular typing of Mycobacterium tuberculosis isolates from a rural area of Kanpur by spoligotyping and mycobacterial interspersed repetitive units (MIRUs) typing Infect Genet Evol 8 621-626

Sharma A, Dutta BS, Rasul ES, Barkataki D, Saikia A and Hazarika NK (2017) Prevalance of Vibrio cholerae O1 serogroup in Assam, India: A hospital-based study Indian J Med Res 146 401-408

Sharma S, Mittal S, Mallik S and Virdi JS (2006) Molecular characterization of beta-lactamase genes blaA and blaB of Yersinia enterocolitica biovar 1A FEMS Microbiol Lett 257 319-327

Sharma S, Parida M, Shukla J and Rao PV (2011) Molecular epidemiology of novel swine origin influenza virus (SOIV) from Gwalior, India, 2009 Virol J 8280

Sharma S, Vijayachari P, Sugunan AP, Natarajaseenivasan K and Sehgal SC (2006) Seroprevalence of leptospirosis among high-risk population of Andaman Islands, India Am J Trop Med Hyg 74 278-283

Sikri K, Batra SD, Nandi M, Kumari P, Taneja NK and Tyagi JS (2015) The pleiotropic transcriptional response of Mycobacterium tuberculosis to vitamin $\mathrm{C}$ is robust and overlaps with the bacterial response to multiple intracellular stresses Microbiology 161 739-753

Singhal N, Kumar M and Virdi JS (2014) Molecular analysis of $\beta$ lactamase genes to understand their differential expression in strains of Yersinia enterocolitica biotype 1A Sci Rep 4 5270

Singhal N, Srivastava A, Kumar M and Virdi JS (2015) Structural variabilities in $\beta$-lactamase (bla $\mathrm{A}$ ) of different biovars of Yersinia enterocolitica: Implications for $\beta$-lactam antibiotic and $\beta$-lactamase inhibitor susceptibilities PLoS One 10 e0123564

Singh OP, Hasker E, Boelaert M and Sundar S (2016) Elimination of visceral leishmaniasis on the Indian subcontinent $L$ ancet Infect Dis 16 e304-309

Singh Y, Klimpel KR, Goel S, Swain PK and Leppla SH (1999) 
Oligo-merization of anthrax toxin protective antigen and binding of lethal factor during endocytic uptake into mammalian cells Infect Immun 67 1853-1859

Singh Y, Ivins BE and Leppla SH (1998) Study of immunization against anthrax with the purified recombinant protective antigen of Bacillus anthracis Infect Immun 66 3447-3448

Singh SS, Naiyer S, Bharadwaj R, Kumar A, Singh YP, Ray AK, Subbarao N, Bhattacharya A and Bhattacharya S (2018) Stress-induced nuclear depletion of Entamoeba histolytica 32-52 exoribonuclease EhRrp6 and its role in growth and erythrophagocytosis J BiolChem 293 16242-16260

Sood U, Bajaj A, Kumar R, Khurana S and Kalia VC (2018) Infection and microbiome: impact of tuberculosis on human gut microbiome of Indian cohort Indian J Microbiol 58 123-125

Srivastava S, Pasipanodya JG, Ramachandran G, Deshpande D, Shuford S, Crosswell HE, Cirrincione KN, Sherman CM, Swaminathan S and Gumbo T (2016) A long-term coperfused disseminated tuberculosis-3D liver hollow fiber model for both drug efficacy and hepatotoxicity in babies E Bio Medicine 6 126-38

Swaminathan S (2014) Preventive treatment for tuberculosis in people with HIV Lancet 384 644-646

Talwar GP, Singh P, Atrey N and Gupta JC (2016) Making of a highly useful multipurpose vaccine $J$ Transl Sci 1 69-73

Thungapathra M, Sharma C, Gupta N, Ghosh RK, Mukhopadhyay A, Koley H, Nair GB and Ghosh A (1999) Construction of a recombinant live oral vaccine from a non-toxigenic strain of Vibrio cholerae $\mathrm{O} 1$ serotype inaba biotype E1 Tor and assessment of its reactogenicity and immunogenicity in the rabbit model Immunol Lett 68219 27

Tewari M, Mishra RR and Shukla HS (2010) Salmonella typhi and gallbladder cancer: report from an endemic region. Hepatobiliary Pancreat Dis Int 9 524-530
Tiwari S, Ghoshal U, Ghoshal UC, Dhingra S, Pandey R, Singh M, Ayyagari A and Naik S (2008) Frequency of Helicobacter pylori and CagA antibody in patients with gastric neoplasms and controls: the Indian enigma Dig Dis Sci 53 $1215-1222$

Tiwari S, Singh RK, Tiwari R and Dhole TN (2012) Japanese encephalitis: a review of the Indian perspective Braz $J$ Infect Dis 16 564-573

Thomas S K, Iravatham CC, Moni BH, Kumar A, Archana BV, Majid M, Priyadarshini Y, Rani PS, Valluri V, Hasnain SE and Ahmed N (2012) Modern and ancestral genotypes of Mycobacterium tuberculosis from Andhra Pradesh, India PLoS One 6 e27584

Turankar RP, Pandey S, Lavania M, Singh I, Nigam A, Darlong J, Darlong F and Sengupta U (2015) Comparative evaluation of PCR amplification of RLEP, 16S rRNA, rpoT and Sod A gene targets for detection of $M$. leprae DNA from clinical and environmental samples Int J Mycobacterio 4 54-59

Vijayachari P, Sehgal SC, Goris MG, Terpstra WJ and Hartskeerl RA(2003) Leptospirainter rogans serovar Valbuzzi: a cause of severe pulmonary haemorrhages in the Andaman Islands.J Med Microbiol 52 913-918

Vijayachari P and Sehgal SC (2006) Recent advances in the laboratory diagnosis of leptospirosis and characterisation of leptospires Indian J Med Microbiol 24 320-322

Zaka-ur-Rab Z, Abqari S, Shahab T, Islam N and Shukla I (2012) Evaluation of salivary anti-Salmonella typhi lipopolysaccharide IgA ELISA for serodiagnosis of typhoid fever in children Arch Dis Child 97 236-238

Zaman M, Chowdhary K, Kaur G and Shah A (2018) Amoebic colonic perforation presenting as peritonitis in emergency, incidence and outcome: Our experience Maedica 13 5154. 